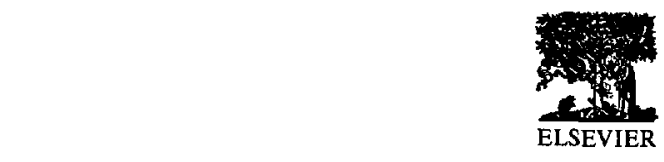

\title{
ACETOACETATE AND $\beta$-D-HYDROXYBUTYRATE AS ENERGY SUBSTRATES DURING EARLY BOVINE EMBRYO DEVELOPMENT IN VITRO
}

\section{E. Gómez}

Centro de Investigación Aplicada y Tecnologia Agroalimentaria Centro de Selección y Reproducción Animal, Gijón, Asturias, Spain

Received for publication: June 12, 1996

Accepted: November 5, 1996

\begin{abstract}
We examined the effects of acetoacetate and other metabolic products of fatty acid oxidation on early bovine embryo development. In vitro produced bovine zygotes were cultured in modified-synthetic oviduct fluid medium supplemented with acetoacetate, acetoacetate derivatives, acetyl $\mathrm{COA}$ precursors and lithium chloride. Acetoacetate and all acetoacetate derivatives, with the exception of the ethyl ester, supported in vitro development up to the hatched blastocyst stage at rates similar to that of controls supplemented with lactate/pyruvate. The optimal concentration of acetoacetate in supporting embryo development was $3.6 \mathrm{mM}$; addition of 1.8 and $3.6 \mathrm{mM}$ lithium chloride did not significantly affect embryo development, while $7.2 \mathrm{mM}$ was inhibitory. Hatched blastocysts cultured with $3.6 \mathrm{mM}$ acetoacetate contained a similar number of cells as the lactate/pyruvate control group. It can be concluded that in vitro produced bovine embryos can develop using ketone bodies as energy substrates, which could be derived in vivo from endogenous lipids.
\end{abstract}

- 1997 by Elsevier Science Inc.

Key words: acetoacetate, hydroxybutyrate, bovine, embryo, lipid

\section{INTRODUCTION}

In vitro produced (IVP) embryos display cryobiological features different from their in vivo counterparts $(13,21)$. Bovine IVP morulae show poor survival after freezing $(15,20)$, although survival after freezing/thawing increases as IVP morulae develop to the hatched blastocyst stage, particularly whe $\mathrm{n}$ the blastocysts are frozen by vitrification

Acknowledgments

The author thanks F. Garcia for COC recovery, A. Novelli and M.T. FernándezSánchez for technical support and useful suggestions, and Dr. H.J. Leese for valuable suggestions and critical review of the manuscript. 
$(3,5,15)$. Mechanical delipidation of IVP bovine embryos leads to an increased survival after freezing and thawing $(4,14,30)$. If embryos could be induced to use endogenous lipids as energy sources, this might represent a way of decreasing their fat content and increasing their ability to survive cryopreservation. It would also improve embryo quality generally. Bovine IVP embryos can utilize different exogenous energy substrates during their development $(18,19,22,23,28)$, but the potential role of fatty acid oxidation and of the metabolic products, acetoacetate and $\beta$-D-hydroxybutyrate, during early bovine development has not been examined. The aim of this work was therefore to characterize bovine embryo development in the presence of 1) different acetoacetate derivatives; 2 ) acetyl CoA precursors (acetate, acetoacetate and $\beta$-D-hydroxybutyrate); 3) different concentration of acetoacetate; and 4) different concentrations of lithium, since one derivative of acetoacetate is the lithium salt.

\section{MATERIALS AND METHODS}

Oocyte Recovery and Maturation

Ovaries recovered from slaughtered Asturiana de los Valles and Holstein Friesian

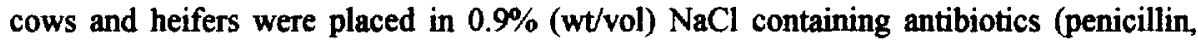
100 units $/ \mathrm{ml}$ and streptomycin sulfate, $100 \mathrm{mg} / \mathrm{ml}$ ) and maintained at 30 to $33^{\circ} \mathrm{C}$ until recovery of cumulus-oocyte complexes (COCs). Ovaries were washed twice in distilled water and once in freshly prepared saline and antibiotics. The COCs were aspirated from 2- to $7-\mathrm{mm}$ antral follicles through an $18 \mathrm{G}$ needle connected to a vacuum system and recovered into a 50-ml plastic tube (Nunc, Roskilde, Denmark). Follicular fluid and COCs were placed in an ovum concentrator (Em-Con, Eurofomento Pecuario, Madrid, Spain; 8) and rinsed 3 times with holding medium (consisting of PBS, pyruvate $0.16 \mathrm{mM}$, BSA $3 \mathrm{~g} / \mathrm{L}$ and gentamycin solution [Gibco, Paisley, Scotland] $5 \mu \mathrm{l} / \mathrm{ml}$ ). Only oocytes enclosed in a compact cumulus with and evenly granulated cytoplasm were selected for maturation. The COCs were washed 3 times in maturation medium comprised of Medium 199 (Sigma, Madrid, Spain), fetal bovine serum (FBS, 10\% v/v) and FSHp (20 $\mu \mathrm{g} / \mathrm{ml}$; Schering-Plough Animal Health, Madrid, Spain; 25). Maturation was performed by culturing approximately $100 \mathrm{COCs}$ in $500 \mu \mathrm{l}$ of maturation medium in four-well dishes. Culture conditions were $39^{\circ} \mathrm{C}, 5 \% \mathrm{CO}_{2}$ in air and high humidity throughout.

\section{In Vitro Fertilization}

In vitro fertilization was carried out using procedures similar to those previously reported by Parrish et al. (17). Frozen semen from a single bull was thawed into a warmed tube, transferred to the top of a Percoll 45 to $90 \%$ gradient contained in a $15-\mathrm{ml}$ polystyrene tube, and centrifuged at $700 \times \mathrm{g}$ for $30 \mathrm{~min}$. The sperm pellet was diluted with $5 \mathrm{ml}$ of sperm-TALP (sp-TALP), centrifuged for $10 \mathrm{~min}$ at $200 \mathrm{x} \mathrm{g}$ and the 
supernatant aspirated to leave a pellet approximately $100 \mu \mathrm{l}$ in volume. Sperm concentration was determined with a hemocytometer. Fertilization medium (fert-TALP) with heparin (10 $\mu \mathrm{g} / \mathrm{ml}$; Calbiochem, La Jolla, CA) was used to dilute the spermatozoa. After 23 to $24 \mathrm{~h}$ of maturation, the COCs were washed 3 times in wash-TALP and placed in four-well culture dishes containing pre-equilibrated fertilization medium. Spermatozoa were then added to a concentration of approximately $2 \times 10^{6}$ cells $/ \mathrm{ml}$ in $500 \mu \mathrm{l}$ of medium per well containing $100 \mathrm{COCs}$. In vitro fertilization was accomplished by incubating oocytes and sperm cells together for $18 \mathrm{~h}$.

\section{In Vitro Embryo Culture}

Embryo cultures were carried out in modified synthetic oviduct fluid medium (mSOF; 28), with cysteamine (50 $\mu \mathrm{M}$; Sigma) and BSA ( $\mathrm{g} / \mathrm{L}$; Sigma), to which FBS $(10 \% \mathrm{v} / \mathrm{v})$ was added $48 \mathrm{~h}$ post insemination. Lactate and pyruvate were substituted by other putative energy substrates where indicated. Culture media were renewed on Days 3 and 6 of culture. Media were prepared weekly and used fresh at $\mathrm{pH} 7.2$ to 7.3 and osmolality of 270 to $280 \mathrm{mOsm}$. Then 50 - to $70-\mu \mathrm{l}$ droplets $(2 \mu \mathrm{l} / \mathrm{embryo})$ of the correspondent culture medium were prepared in four-well culture dishes under mineral oil and allowed to equilibrate in the incubator for at least $2 \mathrm{~h}$ before the addition of embryos. Fertilized oocytes were vortexed for $2 \mathrm{~min}$ in holding medium at medium speed to separate cumulus cells, rapidly washed 3 times in holding medium and twice in the corresponding culture medium prior to a 9-d period of culture. Embryo development was accessed on Days $2,6,7,8,9$, and 10 post insemination.

Experiment 1. The following acetoacetate derivatives were tested as putative energy substrates for in vitro embryo culture at a concentration of $3.6 \mathrm{mM}$ in mSOF: 1) lithium acetoacetate (Sigma); 2) ethyl acetoacetate (Sigma); 3) sodium acetoacetate, obtained by the hydrolysis of ethyl acetoacetate with equimolar $\mathrm{NaOH}$ solution with further lyophylization to eliminate water and the ethanol formed; the crystallized sodium acetoacetate prepared in this manner was stored frozen at $-20^{\circ} \mathrm{C}$ and used not more than 7 d later; 4) sodium acetoacetate + ethanol (as in 3) but without lyophylization. A lactate/pyruvate $(3.30 \mathrm{mM} / 030 \mathrm{mM})$ solution in $\mathrm{mSOF}$ acted as a positive control (+LP). A negative control (-LP) contained lactate/pyruvate-free mSOF.

Experiment 2. The following acetyl CoA precursors and related compounds were tested for their ability to influence IVP bovine embryo development: 1) sodium acetoacetate (3.6 mM); 2) sodium $\beta$-D-hydroxybutyrate (Sigma H-0265, $3.6 \mathrm{mM}$ ); and 3) sodium acetate $(7.2 \mathrm{mM}$ synthesized from glacial acetic acid treated with equimolar $\mathrm{NaOH}$ solution; Panreac, Barcelona, Spain), were tested in comparison to $+\mathrm{LP}$ as the control. 
Experiment 3. Because acetoacetate at a concentration of $10 \mathrm{mM}$ has been reported to retard development of mouse embryos in vitro (16), lower concentrations of sodium acetoacetate were tested in an attempt to overcome this inhibitory effect and to optimize in vitro culture conditions. Acetoacetate concentrations of $1.8,3.6$ and $7.2 \mathrm{mM}$ in mSOF were tested and compared with $+\mathrm{LP}$ and $-\mathrm{LP}$ as the controls.

Experiment 4. The effects of lithium on in vitro embryo development were tested by replacing sodium chloride with lithium chloride in whole $\mathrm{mSOF}$, to give final concentrations of lithium of $1.8,3.6$ and $7.2 \mathrm{mM}$; +LP served as the control group.

\section{Cell Counts}

The cell numbers in hatched blastocyst obtained at Days 8 and 9 post insemination from Experiments 1,2 and 3, cultured in whole $\mathrm{mSOF}(+\mathrm{LP})$ and $3.6 \mathrm{mM}$ acetoacetate, were determined. Blastocysts were maintained for $20 \mathrm{~min}$ in hypotonic solution $(0.09 \%$ $w / v$ of sodium citrate in double-distilled water); fixed with methanol, acetic acid and double-distilled water (3:2:1); and stained with Giemsa $(1 / 20 \mathrm{v} / \mathrm{v})$ for $15 \mathrm{~min}$. Cell counting was carried out at $\times 200$ with a light microscope.

\section{Statistical Analysis}

Data were analyzed by ANOVA. The numbers of replicates and treatments were considered as fixed effects. The Ryan-Einot-Gabriel-Welsch Multiple F test (SAS, 1989) for the different variables was used to estimate the significance of mean values. Data were expressed as mean percentages \pm SEM of the cultured oocytes.

\section{RESULTS}

Experiment 1

The results of Experiment 1 are shown in Table 1. Sodium acetoacetate and lithium acetoacetate gave rates of blastocyst formation comparable to the positive control group ( $+L P, P<0.05$ ), while ethyl acetoacetate was detrimental to embryo development, with no blastocysts being formed. Sodium acetoacetate significantly $(P<0.05)$ improved the rate of hatched blastocysts formation compared with the negative control group (-LP).

Experiment 2

Table 2 shows the results of Experiment 2. No significant differences were obtained between any group for development to the hatched blastocyst stage. $\beta$-Dhydroxybutyrate supported embryo developmental rates similar to those observed for 
acetoacetate and lactate/pyruvate (+LP control). A nonsignificant, lower blastocyst expansion and hatching rate occurred in the acetate group.

Table 1. Development to the hatched blastocyst stage of IVP bovine oocytes cultured in $\mathrm{mSOF}$ with different acetoacetate-based molecules $(3.6 \mathrm{mM})$ as energy sources replacing lactate and pyruvate.

\begin{tabular}{|c|c|c|c|c|c|c|}
\hline \multirow[b]{2}{*}{ Group } & \multirow[b]{2}{*}{$\mathbf{n}$} & \multirow{2}{*}{$\begin{array}{c}\% \\
\text { Cleaved }\end{array}$} & \multirow{2}{*}{$\begin{array}{c}\% 5 \text { to } 8 \\
\text { Cells }\end{array}$} & \multicolumn{3}{|c|}{$\%$ Blastocysts } \\
\hline & & & & Total & Expanded & Hatched \\
\hline Lithium & 114 & $61.61^{\mathrm{ab}}$ & $43.27^{\mathrm{a}}$ & $28.27^{a}$ & $17.70^{\mathrm{a}}$ & 13.29 \\
\hline Acetoacetate & & \pm 3.28 & \pm 4.47 & \pm 3.06 & \pm 3.00 & \pm 2.72 \\
\hline Sodium & 115 & $68.51^{\mathrm{ab}}$ & $47.22^{\mathrm{a}}$ & $27.90^{\mathrm{a}}$ & $19.12^{\mathrm{a}}$ & $16.54^{\mathrm{a}}$ \\
\hline $\begin{array}{l}\text { Acetoacetate } \\
\text { (lyophylized) }\end{array}$ & & \pm 2.01 & \pm 2.58 & \pm 3.62 & \pm 3.17 & \pm 2.78 \\
\hline Sodium & 113 & $70.64^{a}$ & $49.09^{\mathrm{a}}$ & $28.70^{\mathrm{a}}$ & $19.61^{\mathrm{a}}$ & 13.44 \\
\hline $\begin{array}{l}\text { Acetoacetate } \\
\text { (+ ethanol) }\end{array}$ & & \pm 1.61 & \pm 3.19 & \pm 3.44 & \pm 2.42 & \pm 2.26 \\
\hline Ethyl-ester & 111 & $29.64^{b}$ & $2.61^{b}$ & $0.00^{b}$ & ---- & $\cdots$ \\
\hline Acetoacetate & & \pm 1.81 & \pm 1.60 & & & \\
\hline \multirow[t]{2}{*}{$+\mathrm{LP}$} & 110 & $67.25^{\mathrm{ab}}$ & $41.81^{\mathrm{a}}$ & $29.07^{\mathrm{a}}$ & 13.57 & 9.96 \\
\hline & & \pm 2.33 & \pm 3.88 & \pm 3.68 & \pm 3.06 & \pm 2.50 \\
\hline \multirow[t]{2}{*}{$-\mathrm{LP}$} & 112 & $54.59^{\mathrm{C}}$ & $13.47^{b}$ & $7.15^{b}$ & $2.58^{\mathrm{b}}$ & $0.00^{b}$ \\
\hline & & \pm 2.54 & \pm 2.21 & \pm 2.00 & \pm 1.60 & \\
\hline
\end{tabular}

$n=$ number of matured oocytes; +LP and -LP represents $\mathrm{mSOF}$ with and without lactate/pyruvate added, respectively. Percentages of embryos with 5 to 8 cells, blastocysts, expanded blastocysts and hatched blastocysts were determined on Days 2, 8, 9 and 10 post insemination, respectively.

${ }^{a-c}$ Mean values with different superscripts are significantly different $(\mathrm{P}<0.05)$. Data from 3 replicates.

Experiment 3

Table 3 shows that $3.6 \mathrm{mM}$ was the most favorable concentration of acetoacetate in supporting embryo development. Acetoacetate $7.2 \mathrm{mM}$ was detrimental and acetoacetate $1.8 \mathrm{mM}$ was insufficient to enable blastocysts to form at a rate similar to that in $3.6 \mathrm{mM}$ acetoacetate. 
Table 2. Development to hatched blastocyst stage of IVP bovine oocytes cultured in mSOF with different acetyl CoA precursors as energy substrates replacing lactate and pyruvate.

\begin{tabular}{lcccccc}
\hline & & \% & $\% 5$ to 8 & \multicolumn{3}{c}{ \% Blastocysts } \\
\cline { 6 - 7 } Group & $\mathrm{n}$ & Cleaved & Cells & Total & Expanded & Hatched \\
\hline Acetoacetate & 112 & 59.34 & 34.67 & 24.28 & $15.37^{\mathrm{a}}$ & 12.59 \\
$(3.6 \mathrm{mM})$ & & \pm 3.37 & \pm 1.97 & \pm 3.34 & \pm 2.73 & \pm 2.53 \\
& & & & & & \\
Hydroxy- & 113 & 56.94 & 33.24 & 20.69 & 15.29 & 11.60 \\
butyrate & & \pm 2.75 & \pm 2.18 & \pm 3.08 & \pm 2.57 & \pm 1.52 \\
& & & & & & \\
Acetate & 112 & 54.70 & 26.94 & 17.99 & 8.99 & 3.60 \\
$(7.2 \mathrm{mM})$ & & \pm 3.58 & \pm 1.86 & \pm 2.96 & \pm 2.09 & \pm 1.30 \\
& & & & & & \\
$+\mathrm{LP}$ & 110 & 60.29 & 37.68 & 25.75 & 14.78 & 9.24 \\
& & \pm 3.27 & \pm 1.88 & \pm 3.54 & \pm 3.08 & \pm 2.70
\end{tabular}

$\mathbf{n}=$ number of matured oocytes; +LP represents mSOF with lactate/pyruvate added. Percentages of embryos with 5 to 8 cells, blastocysts, expanded blastocysts and hatched blastocysts were determined on Days $2,8,9$ and 10 post insemination, respectively. Data from 3 replicates.

\section{Experiment 4}

Effects of different concentrations of lithium can be seen in Table 4 . Concentrations of 1.8 and $3.6 \mathrm{mM}$ lithium did not affect early embryo development up to the hatched blastocyst stage compared with that of the control (lithium $0 \mathrm{mM}$ ), but a concentration of $7.2 \mathrm{mM}$ was inhibitory $(6.32 \%$ blastocyst formation vs $24.47 \%$ for the controls).

\section{Cell Counts}

Table 5 shows that there was no significant difference $(P<0.001)$ between the number of cells in blastocysts produced in the presence of $3.6 \mathrm{mM}$ of acetoacetate and lactate/pyruvate. 
Table 3. Development to hatched blastocyst stage of IVP bovine oocytes cultured in mSOF with different sodium acetoacetate concentrations as energy substrates replacing lactate and pyruvate.

\begin{tabular}{lcccccc}
\hline & & \% & $\% 5$ to 8 & \multicolumn{3}{c}{$\%$ Blastocysts } \\
\cline { 6 - 7 } Group & $\mathrm{n}$ & Cleaved & Cells & Total & Expanded & Hatched \\
\hline Acetoacetate & 192 & 62.93 & 27.95 & 15.63 & 10.47 & 5.42 \\
$1.8 \mathrm{mM}$ & & \pm 4.11 & \pm 3.09 & \pm 2.51 & \pm 2.31 & \pm 2.11 \\
& & & & & & \\
Acetoacetate & 193 & 71.54 & 36.89 & $21.67^{\mathrm{a}}$ & $14.24^{\mathrm{c}}$ & $12.19^{\mathrm{c}}$ \\
$3.6 \mathrm{mM}$ & & \pm 1.73 & \pm 4.14 & \pm 3.10 & \pm 2.64 & \pm 1.52 \\
& & & & & & \\
Acetoacetate & 193 & 61.20 & 22.01 & 9.85 & 5.24 & $1.52^{\mathrm{d}}$ \\
$7.2 \mathrm{mM})$ & & \pm 3.53 & \pm 2.23 & \pm 2.38 & \pm 2.19 & \pm 1.50 \\
& & & & & & \\
+ LP & 193 & 68.53 & 34.62 & $22.38^{\mathrm{a}}$ & $14.30^{\mathrm{c}}$ & 8.04 \\
& & \pm 3.38 & \pm 4.00 & \pm 3.40 & \pm 2.76 & \pm 2.83 \\
-LP & & & & & \\
& 191 & 57.21 & 16.43 & $7.43^{\mathrm{b}}$ & $2.18^{\mathrm{d}}$ & $0.00^{\mathrm{d}}$ \\
& & \pm 2.42 & \pm 2.43 & \pm 1.61 & \pm 1.53 &
\end{tabular}

$\mathbf{n}=$ number of matured oocytes; $+\mathrm{LP}$ ad $-\mathrm{LP}$ represents $\mathrm{mSOF}$ with and without lactate/pyruvate added, respectively. Percentages of embryos with 5 to 8 cells, blastocysts, expanded blastocysts and hatched blastocysts were determined on Days 2, 8, 9 and 10 post insemination, respectively.

Mean values with different superscripts are significantly different $\left({ }^{a, b} P<0.05 ;{ }^{c, d} P<0.01\right)$. Data from 5 replicates.

\section{DISCUSSION}

It is known that the ketone bodies, acetoacetate and $\beta$-D-hydroxybutyrate, may be utilized in aerobic metabolism and are quantitatively important as energy sources. Adult tissues such as heart and kidney cortex utilize acetoacetate in preference to glucose. The present study demonstrates that acetoacetate can support IVP bovine embryo development. Concentrations of acetoacetate $(10 \mathrm{mM})$ and $\beta$-D-hydroxybutyrate $(>16$ $\mathrm{mM}$ ) higher than those used here adversely affected mouse preimplantation embryo development in vitro (16). Such concentrations are found in human diabetic serum with ketoacidosis (HDS-K; 34). Furthermore, HDS-K yielded teratogenic effects in early somite rat embryos (33). These negative effects on early and late development were mainly attributed to $\beta$-D-hydroxybutyrate, while acetoacetate had little or no teratogenic potential in diabetic rats (24), except if added together with $\beta$-D-hydroxybutyrate and 
Table 4. Development to hatched blastocyst stage of IVP bovine oocytes cultured in whole mSOF (lactate/pyruvate added with different $\mathrm{mM}$ concentrations of lithium).

\begin{tabular}{|c|c|c|c|c|c|c|}
\hline \multirow[b]{2}{*}{ Group } & \multirow[b]{2}{*}{$\mathbf{n}$} & \multirow{2}{*}{$\begin{array}{c}\% \\
\text { Cleaved }\end{array}$} & \multirow{2}{*}{$\begin{array}{c}\% 5 \text { to } 8 \\
\text { Cclls }\end{array}$} & \multicolumn{3}{|c|}{$\%$ Blastocysts } \\
\hline & & & & Total & Expanded & Hatched \\
\hline Lithium & 111 & 60.38 & 38.96 & $20.86^{\mathrm{a}}$ & $14.54^{\mathrm{a}}$ & $6.37^{\mathrm{a}}$ \\
\hline $1.8 \mathrm{mM}$ & & \pm 1.78 & \pm 2.91 & \pm 2.05 & \pm 1.93 & \pm 2.11 \\
\hline Lithium & 109 & 60.70 & 44.22 & $24.00^{a}$ & $14.75^{\mathrm{a}}$ & $7.36^{\mathrm{a}}$ \\
\hline $3.6 \mathrm{mM}$ & & \pm 3.10 & \pm 3.85 & \pm 3.02 & \pm 2.15 & \pm 2.08 \\
\hline Lithium & 110 & 66.56 & 24.53 & $6.32^{\mathrm{b}}$ & $1.75^{\mathrm{b}}$ & $0.00^{h}$ \\
\hline $7.2 \mathrm{mM}$ & & \pm 2.14 & \pm 1.84 & \pm 1.09 & \pm 1.23 & \\
\hline Lithium & 111 & 63.04 & 43.38 & $24.47^{\mathrm{a}}$ & $13.49^{\mathrm{a}}$ & $9.07^{\mathrm{a}}$ \\
\hline $0 \mathrm{mM}$ (control) & & \pm 2.33 & \pm 2.85 & \pm 2.52 & \pm 1.54 & \pm 1.42 \\
\hline
\end{tabular}

$\mathbf{n}=$ number of oocytes. ${ }^{a, b}$ Values with different superscripts are significantly different $(\mathrm{P}<0.05)$. Percentages of embryos with 5 to 8 cells, blastocysts, expanded blastocysts and hatched blastocysts were determined on Days 2, 8, 9 and 10 post insemination, respectively.

Data from 3 replicates.

Table 5. Number of cells in hatched blastocyst cultured in acetoacetate $3.6 \mathrm{mM}$ and in whole mSOF (lactate/pyruvate).

\begin{tabular}{lcc}
\hline \multicolumn{1}{c}{ Group } & $\begin{array}{c}\text { Number of blastocysts } \\
\text { counted }\end{array}$ & $\begin{array}{c}\text { Number of cells } \\
\text { (means } \pm S E \text { ) }\end{array}$ \\
\hline Acetoacetate $3.6 \mathrm{mM}$ & 11 & $124.09 \pm 4.70$ \\
Lactate/pyruvate & 10 & $126.00 \pm 4.21$ \\
\hline
\end{tabular}

Blastocysts were obtained from 7 different replicates $(\mathrm{P}<0.001)$.

glucose (32). In the present work, $7.2 \mathrm{mM}$ of acetoacetate significantly reduced blastocyst formation and hatching, and $1.8 \mathrm{mM}$ of acetoacetate was insufficient to satisfy the energy requirements of the embryos; the quality of blastocysts formed with $3.6 \mathrm{mM}$ of acetoacetate, in terms of the number of cells, was comparable to that in the presence of lactate/pyruvate. 
Acetoacetate could be derived from either endogenous (embryonic) or exogenous (female tract) sources, or both. Maximal blood levels of ketone bodies in healthy cows are $0.48 \mathrm{mM}$ for acetoacetate and $0.85 \mathrm{mM}$ for $\beta$-D-hydroxybutyrate (reviewed by Courcel; 2), or below the concentration required to sustain embryo development. It would be interesting to determine acetoacetate and hydroxybutyrate levels in oviductal fluid, where a variety of lipids have been reported in the bovine $(9,11)$. None of these lipids are required for bovine embryo development $(1,26)$. That IVP bovine embryos are capable of

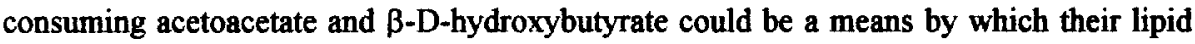
stocks could be degraded. Decreasing lipid content in this way by nonmechanical means might improve the ability of the embryos to be cryopreserved $(4,14,30)$. It has been suggested for ovine embryos that a direct association exists between lipid droplets and mitochondria, which may represent an important source of energy in vivo (6). Such lipids may be used not only when substrate availability is low (29), but under normal conditions. In this respect, features of in vitro-cultured bovine morulae, such as an absence of compaction, low survival after freezing-thawing, and low buoyant density, could have a common origin related to the continuous presence of a high level of lipid.

The present data showed that acetoacetate-salt derivatives supported in vitro embryo development up to the hatched blastocyst stage. Embryo development was significantly decreased by $7.2 \mathrm{mM}$ lithium, but not at the other concentrations tested (1.8 and $3.6 \mathrm{mM}$ ). Lithium adversely affects development in post-implantation rat and mouse embryos with $10 \pm 2$ somite pairs (7) at concentrations of $5 \mathrm{mM}$ and below. Lithium has different growth-stimulating effects on adult cell types in vitro (mammary gland explants, cultured fibroblasts and kidney epithelial cells), which may be related to the effect on other intracellular ions (e.g., $\left.\mathrm{Ca}^{2+}, \mathrm{Mg}^{2+} ; 12\right)$, which, in turn, are thought to regulate growth. There are no studies on the effect of lithium on preimplantation development. Although the ethyl ester derivative of acetoacetate might have been expected to enter the embryos readily and be hydrolyzed by esterases, it had a negative effect on development, even compared with those embryos cultured in the absence of energy substrates (-LP).

Embryo culture in the presence of other acetyl CoA precursors, $\beta-D$ hydroxybutyrate and acetate, also supported development up to the hatched blastocyst stage, though acetate gave statistically non significantly lower embryo development than the other experimental groups. This is consistent with low utilization of acetate reported in ovine and bovine embryos (31), and with low development of IVP bovine (18) and rabbit (10) embryos cultured in medium containing acetate. Because the hydroxybutyrate/acetoacetate ratio depends on the NADH/NAD+ ratio in the mitochondria (27), it would be interesting to vary the proportions of both molecules in the culture medium. 
In conclusion, IVP bovine embryos can develop to the hatched blastocyst stage in the presence of acetoacetate and $\beta$-D-hydroxybutyrate. Embryos developing in $3.6 \mathrm{mM}$ acetoacetate had a cell number similar to those in lactate/pyruvate.

\section{REFERENCES}

1. Bavister BD, Rose-Hellekant TA, Pinyopummintr T. Development of in vitro matured/in vitro fertilized bovine embryos into morulae and blastocysts in defined culture media. Theriogenology 1992;37:127-146.

2. Courcel B. Constantes bochimiques sanguines de la vache laitiere. Thèse. Publications de L'Ecole Nationale Vétérinaire de Lyon 1972;78:48-52.

3. Delval A, Ectors FJ, Touati K, Beckers J-F, Ectors F. Vitrification of bovine embryos produced in vitro: survival, hatching and pregnancy rates. Theriogenology 1996;45:178 abstr.

4. Diez C, Le Bourhis D, Heyman Y, Renard JP. Effect of partial lipid removal from in vitro produced bovine zygotes on further development in vitro and on the freezing tolerance of blastocysts. Theriogenology 1996;45:166 abstr.

5. Dinnyes A, Carolan C, Lonergan $P$, Solti L, Massip A, Mermillod P. In vitro survival of in vitro produced (IVP) bovine embryos frozen or vitrified by techniques suitable for direct transfer. Theriogenology 1995;43:197 abstr.

6. Dorland M, Gardner DK, Trounson AO. Serum in synthetic oviduct fluid causes mitochondrial degeneration in ovine embryos. J Reprod Fertil 1995;13:70 abstr.

7. Hansen DK, Walker RC, Grafton TF. Effect of lithium carbonate on mouse and rat embryos in vitro. Teratology 1990;41:155-160.

8. Hawk HW, Wall RJ. Improved yields of bovine blastocysts from in vitro-produced oocytes. I. Selection of oocytes and zygotes. Theriogenology 1994;41:1571-1583.

9. Henault MA, Killian GJ. Synthesis and secretion of lipids by bovine oviductal mucosal explants. J Reprod Fertil 1993;98:431-438.

10. Kane MT. Minimal nutrient requirements for culture of one-cell rabbit embryos. Biol Reprod 1987;37:775-778.

11. Killian GJ, Chapman DA, Kavanaugh JF, Deaver DR, Wiggin HB. Changes in phospholipids cholesterol and protein content of oviductal fluid of cows during the estrous cycle. J Reprod Fertil 1989;86:419-426.

12. Lazarus JH. Endrocrine and Metabolic Effects of Lithium. New York: Plenum Publishing Corporation. 1986:46-48.

13. Leibo SP, Loskutoff NM. Cryobiology of in vitro-derived bovine embryos. Theriogenology 1993;39:81-94.

14. Leibo SP, Pollard JW, Martino A. Chilling and freezing sensitivity of "reassembled" in vitro-derived bovine embryos. Theriogenology 1995;43:265 abstr. 
15. Lui $Y$, Wang $S$, Holyoak GR, Bunch TD. Survival rates of in vitro produced bovine embryo cryopreserved by controlled slow-freezing, fast-freezing and vitrification. Theriogenology 1996;45:177 abstr.

16. Moley KH, Vaughn WK, Diamond MP. Manifestations of diabetes mellitus on mouse preimplantation development: effect of elevated concentrations of metabolic intermediates. Hum Reprod 1994;9:113-121.

17. Parrish JJ, Susko-Parrish JL, Leibfried-Rutledge ML, Critser ES, Eyestone WH, First NL. Bovine in vitro fertilization with frozen-thawed semen. Theriogenology 1986;25:591-600.

18. Peura TT. Effects of acetate, citrate and malate on development of in vitro fertilized bovine embryos. Theriogenology 1990;33:296 abstr.

19. Pinyopummintr T, Bavister BD. Minimum energy substrates requirements for early cleavage stages of bovine embryo development in vitro. Theriogenology 1995;43:299 abstr.

20. Pollard JW, Leibo SP. Comparative cryobiology of in vitro and in vivo derived bovine embryos. Theriogenology 1993;39:287 abstr.

21. Pollard JW, Leibo SP. Chilling sensitivity of mammalian embryos. Theriogenology 1994;41:101-106.

22. Rieger D, Loskutoff NM, Betteridge KJ. Developmentally related changes in the metabolism of glucose and glutamine by cattle embryos produced and co-cultured in vitro. J Reprod Fertil 1992;95:585-595.

23. Rosenkrans, Jr. CF, Zeng GQ, McNamara GT, Shoff PK, First NL. Development of bovine embryos in vitro as affected by energy substrates. Biol Reprod 1993;49:459-462.

24. Sadler TW, Hunter, IIIrd ES, Balkan W, Horton, Jr. WE. Effects of maternal diabetes on embryogenesis. Am J Perinatol 1988;5:319-326.

25. Saeki K, Hoshi M, Leibfried-Rutledge ML, First NL. In vitro fertilization and development of bovine oocytes matured with commercially available follicle stimulating hormone. Theriogenology 1990;34:1035-1039.

26. Seidel, Jr. GE, Glass T, Olson SE. Culture of 1-cell bovine embryos to blastocysts in chemically defined media. Biol Reprod 1991;44(Suppl 1):155 (abstr 412).

27. Stryer L. Bioquimica. Barcelona: Editorial Reverte 1988:485 abstr.

28. Takahashi Y, First NL. In vitro development of bovine one-cell embryos: influence of glucose, lactate, pyruvate, amino acids and vitamins. Theriogenology 1992;37:963-978.

29. Thompson G. Defining the requirements for bovine embryo culture. Theriogenology 1996;45:27-40.

30. Ushijima $H$, Yamakawa $H$, Nagashima $H$. Cryopreservation of bovine IVM/IVF embryos at early cleavage stage following removal of cytoplasmic lipid droplets. Theriogenology 1996;45:159 abstr. 
31. Waugh EE, Wales RG. Oxidative utilization of glucose, acetate and lactate by early preimplantation sheep, mouse and cattle embryos. Reprod Fert Dev 1993;5:123-133.

32. Zusman I, Omoy A. Effects of hyperglycemia and ketone bodies on the in vitro development of early somite rat embryos. Pediatr Pathol 1987;7:535-547.

33. Zusman I, Yaffe P, Raz I, Bar-On H, Omoy A. Effects of human diabetic senum on the in vitro development of early somite rat embryos. Teratology 1989b;39:8592.

34. Zusman I, Yaffe P, Ornoy A. Effects of human diabetic serum on the in vitro development of mouse preimplantation embryos. Teratology 1989a;39:581-589. 